\title{
Consumers' Attitude and Product Labeling for GM Food in China and Hormone Induced Milk in the United States
}

\author{
Kalyan (Kal) Chakraborty \\ Associate Professor, School of Business, Emporia State University \\ Box 4057, 1200 Commercial Street, Emporia, KS 66801 \\ Tel: 1-620-341-5913 E-mail: kchakrab@emporia.edu
}

Received: July 30, 2010

Accepted: August 17, 2010

doi:10.5539/ijef.v3n2p3

Paper presented at the Annual Conference of International Society of Business Disciplines, March 22-24, 2009, Las Vegas, NV

\begin{abstract}
This paper reviews some of the recent research findings on consumers' attitude and willingness to pay for genetically modified food (GM food) in China and hormone induced milk in the US. The economic impact studies on mandatory labeling for GM food around the world are also discussed. The general consensus from the impact studies in the literature is that it raises the price of the food products depending on the cost of labeling, labeling characteristics, and the structure of the market. Using survey data from the US consumers this study finds that mandatory labeling for hormone (bST) induced milk would increase the economic benefit to the society raising the consumer and producer surpluses and provides the right to choose in the hands of the consumers.
\end{abstract}

Keywords: Biotechnology, BST-milk, Genetically Modified Food, Economic Value

\section{Introduction}

Agricultural biotechnology is one of the most innovative and promising technologies in this century and has generated worldwide debate over its safety for use in human and animal diet. Today, China is one of the leading nations in the world on agricultural biotechnology which started in 1970s by several research institutions within Chinese Academy of Agricultural Sciences (CAAS) and the China Academy of Scientists (CAS). But it was not until 1986 when under the '863-Program' national high-tech laboratories were established in all major agricultural universities and researchers and scholars started to specialize in the field of biotechnology and genetic engineering (Huang et al. 2004). Chinese government recognizes agricultural biotechnology as a tool for achieving food security, improvement in agricultural productivity and farm income, sustainable development, and its competitive advantage in agricultural export (SSTC, 1990). Rosegrant et al. (2001) estimated that in order to feed the Chinese population by 2020 the cereal production of China must increase by 40 percent. Like most of the developing nations, where majority of the available land resources are already in use or diverted to biofuel production, food supply in China must rely on increased productivity from biotechnology in the future. (Pingali et al, 1997; Jin et al. 2002)

In response to a question by the editor of Science with regard to biotechnology and its concern in the West China's President Jiang Zemin stated, "I believe biotechnology - especially gene research - will bring good to humanity." In his opening speech at the International Rice Conference in Beijing on Sept 15, 2002, President Jiang Zemin restated the importance of agricultural biotechnology in boosting agricultural productivity growth and food security (Rubenstein, 2000). The commitment of Chinese government is reaffirmed on July 2008 when Chinese Primer Wen Jiabao announced that the government will spend additional $\$ 3$ billion for the development of agricultural biotechnology over the next 15 years. This signals China's intent to use biotechnology as a tool to address food security and reaffirms its position that the technology can be used safely for human welfare (Petry and Bugang, 2008). However, China's rapid economics development, industrialization, and urbanization have caused profound changes in its food chain with potential threat to its food security. The outbreak of severe acute respiratory syndrome (SARS) in South China, in the spring of 2003, the food poisoning from carcinogenic substances in Lee Kum Kee's oyster sauce, toxic chemicals in Long Kou rice vermicelli, and the death of hundreds of infants due to bad quality baby milk powder in Anhui in 2004 shocked the public opinion (Ho and Vermeer, 2004). The list continues with two recent incidents of milk and infant powder milk scandals in 2008. After pursuing an aggressive 
policy for commercial production of Bt cotton, Chinese government has recently taken the path of cautious approach toward commercialization of GM products and imposed vigorous safety and testing regulations for all biotech products in the pipeline.

One of the objectives of this paper is to review the recent empirical studies in the literature on consumer attitude and product labeling for GM food in China. The other objective is to review the economic impact studies on product labeling for GM food around the world with a special focus on hormone induced milk production in the US. While there are very few studies analyzing economic impact of mandatory labeling of GM agricultural products, empirical studies on economic impact of labeling hormone induced milk are rare (Chakraborty, 2006).

The organization of this paper is as follows: the next section discusses the consumers' attitude toward GM food in China followed by a section on the issues related to product labeling for GM food. The fourth section reviews economic impact studies on mandatory labeling of GM products around the world and the fifth section discusses the results from an empirical study on economic impact of mandatory labeling for hormone induced milk. Summary and conclusions are in the last section.

\section{Consumers' Attitude toward GM Food in China}

China is one of the first countries in the world to introduce a GM crop commercially and currently the 6th largest producer of biotechnology enhanced plants based on total acreage (3.8 million hectors in 2007, the top five countries are the U.S., Argentina, Brazil, Canada, and India.) and the largest producer of Bt-cotton in the world (54 percent). Since 1997, China has commercialized 6 GM plants - cotton, tomato, sweet pepper, petunia, poplar, and papaya; the three products that are under advanced developmental stage are the insect resistant rice (Bt63) and bacterial blight resistant rice (Xa21) and high oil content canola (International Services for the Acquisition of Agri-biotech Applications, ISAAA). However, the Chinese government has not approved any biotech staple food crops for commercialization even though it has made a significant investment in research and development of agricultural biotechnology in this area (Petry and Bugang, 2008). China has also approved 4 biotech products for import as processing materials - soybeans, corn, canola, and cotton.

One of the controversial issues in agricultural biotechnology is the use of genetically modified (GM) ingredients within food products. Consumers' attitude towards GM food products is generally negative in many developed countries in the European Union and Japan. The negative attitude toward GM products emanates from consumer's perception about unknown environmental and health consequences of GM crops such as, unanticipated allergic responses, the spread of pest resistant and herbicide tolerant to wild plants, and inadvertent toxicity of wildlife (Curtis et al. 2004). In the absence of substantial safety testing for GM food it is possible that such food might pose potential health hazard to the consumers. Surprisingly, most of the health hazards have been discovered long after the GM crops have been already been approved for public use in many countries of the world.

For example, according to a report that between 2005 and 2006 thousands of sheep has died after grazing on post harvest Bt cotton fields in a village in Andhra Pradesh, India. Hundred of farm workers and cotton handlers in Madhya Pradesh, India reported to have suffered from allergy symptoms such as, mild to severe itching, the redness and swelling, followed by skin eruptions after exposure to Bt cotton picking, loading, and handling. A similar incident happened in a town Tuka, in southern Philippines in 2003 where 32 people suddenly suffered from several ailments including headache, dizziness, vomiting, diarrhea, breathing difficulties when 30 hectors of land in the area was being planted with $\mathrm{B} t$ maize. A German farmer grew GM corn (Bt 176) and fed it to his cows when 12 of them died and the rest were destroyed due to "mysterious illness." (Lendman, 2008; Genetic Modifications, 2008)

Chinese people have serious doubt on the government food safety system standards which is incomplete, inspection is weak, and regulations are not strictly enforced. For example, Chinese food scandals regarding contaminated rice, the illegal recycling of moon-cake fillings, and the outbreak of chicken influenza in Hong Kong and Guangzhou have damaged consumers trust in food safety. In April, 2008 more than 100 kindergarteners got sick at a school in Zhuhai, Guangdong province after drinking bacteria infected milk. In September, 2008 thousands infant became sick and developed kidney stone from powder-milk poisoning (produced by Sanlu) causing 4 deaths. This incident led to the largest global recall of Chinese made baby milk powder in the history. Although these incidents, mentioned above, are not related to GM food but it raises a vital question: How safe are the Chinese consumers under the existing safety tests and regulations for food security in China?

A rational consumer evaluates the expected benefits and costs associated with the consumption of a GM food based on his/her education, knowledge, experience, and risk tolerance. Although the scientific conscious for GM food is that they do not pose any health risk to the consumers, but the consumers' perceived risk differs from the scientifically assessed risk. Greenpeace study (2007) found 65 percent of consumers in Shanghai, Beijing, and Guangzhou who is familiar with GM food preferred non-GM food. 
Over the last decade several studies have investigated consumer's attitude toward biotech foods in China such as, $\mathrm{Li}$ et al. 2002; Zhong et al. 2003; Hu and Chen, 2004; Ho and Vermeer, 2004; Curtis et al., 2006; and Lin et al., 2006. The majority of these studies found Chinese consumers are generally favorable or neutral about the use of biotechnology in crop production, feed for raising livestock and poultry, and ingredients in processed food production. To the contrary, European and Japanese consumers are worried about the potential human and environment effects of GM food. Serogaroli et al. (2003) found Italian consumers with higher information about GM food, perceive GM food as a high risk and are willing to pay more for GM free products.

Using survey data from supermarket consumers from three districts in Beijing and one in Shijiazhuang city Ho and Vermeer (2004) found 71 percent of the consumers had heard about transgenic food products however, only 20 percent of the consumers showed understanding of genes and GM products and 60 percent were either neutral or unwilling to buy GM food. Li et al. (2002) using consumer survey data from Beijing found consumers are willing to pay 38 percent premium for GM rice and 16 percent for GM soybean oil. However, the study has several limitations since it used hypothetical GM rice (GM rice has not been commercialized in China) and did not provide sufficient information to the consumers as to the difference between product enhanced GM (rice) and processed enhanced GM (soybean oil). Lin et al. (2006) surveyed 1,100 consumers in 11 large-to-small cities including Beijing and Shanghai and found 46-67 percent of the consumers supported biotech food. The survey also found that the consumers are willing to pay 23-52 percent premium for non-GM soybean oil and 41-74 percent for non biotech rice.

\section{Labeling GM Products}

Many consumers argue and insist on their right to know what they are eating or drinking and their right to choose. Due to consumers' concerns many processors and retailers do not accept GM ingredients to gain consumer confidence. Several countries, both developing and developed have imposed mandatory labeling for GM food. For example, Japan, Russia, South Korea, and EU introduced mandatory labeling for GM food products. China is among the 160 nations that have signed the Cartagena Protocol in 2000 on bio-safety that includes labeling requirements for GM products. Effective March 2002, China introduced new regulations that require mandatory labeling of all foods containing GM ingredients and testing and documentation of the safety of all biotech food ingredients. The labeling policies for GM products differ widely around the world in their nature, scope, coverage, exceptions, and their degree of enforcement (Gruere and Rao, 2007). The major differences among countries with mandatory labeling depends on whether the regulation targets the presence of GM content in the finished product (such as, Australia, New Zealand, and Japan) or on GM technology as a production process (such as, EU, Brazil, and China).

The basic idea behind mandatory labeling requirements is to provide product information and choice to the consumers. However for most of the countries labeling is not primarily about food safety but about consumer information because labeling policies are designed to follow rigorous tests and trials for its approval (Gruere and Rao, 2007). Researchers have argued that mandatory labeling is not a best solution to provide consumer with more choices and product information if it affects country's international trade. For example, Chang (2007) using supermarket scanned data in Nanjing area for GM soybean oil (produced from imported GM soybean) found that the product's market share has decreased by 2 percent since the imposition of mandatory labeling and non-GM soybean oil is out of grocery shelf reducing consumers' choice to just one product. A study by Lin et al (2008) for GM soybean oil in Nanjing area found no significant impact of biotech labeling on consumers' purchasing behavior. For example, the import of GM soybean to China almost doubled since the mandatory labeling for GM products was first introduced in 2003. Li Huping of South China Agricultural University noted that despite China's mandatory labeling policy transgenic papayas are sold in Chinese market unlabelled because vendors know that otherwise they won't be able to sell them (Mahr, 2008).

\section{Review of Studies on Mandatory Labeling of GM Food}

The literature on economic impact studies for mandatory labeling mostly focused GM foods and plants, and rarely on hormone induced milk and milk products. The outcomes from such studies are highly sensitive to the underlying restrictive assumptions on the cost of labeling requirements. The cost of labeling varies depending upon whether or not the starting point of labeling includes the process rather than the final product. For example, the cost of labeling depends upon several labeling characteristics such as, threshold levels, the capacity of the industry to comply with requirements, and government's capacity to enforce and implement the labeling rules (Gruere and Rao, 2007). Any form of labeling whether for GM or non-GM products will cause additional costs. Generally, at the initial stage these costs are borne by the producers but would probably be passed on to the consumers in the form of higher prices at a later stage.

A study in Canada showed that labeling costs could be equivalent to at least 9-10 percent of the retail price of processed food products and 35-40 percent of the producer prices. The study also predicted that biotech and 
non-biotech (labeled as GM-free) would be equally affected by this price increase (ISAAA, 2007). Using data from Australia and New Zealand, KMPG (2001) study found that the cost of implementing mandatory labeling would be US\$9.75 and US\$2.65 per person per year, respectively. NERA (2001) study using UK data under 4 different labeling scenarios found implementation cost per capita per year would be US $\$ 0.23$, US\$0.64, US\$1.77, and US\$3.89. De Leon et al. (2004) found that implementation of mandatory labeling for GM maize in Philippines would raise the consumer price by 10 percent. In a similar study for Quebec, Canada Cloutier (2006) estimated mandatory labeling would impose a fixed cost of US $\$ 20$ and a variable cost of US $\$ 3.50$ per person per year.

Researchers have generally found for markets where the majority of the consumers are concerned with GM food and are willing to pay a premium for non-GM food mandatory labeling could be beneficial for the society, depending on the cost of implementation and structure of the market (i.e., China and Brazil) (Fulton and Giannokes, 2004; Crespi and Marette, 2003). For markets where majority would buy regular GM products while some consumers would prefer non-GM or GM-free products - voluntary labeling could be beneficial, provided the market is efficient and structured (i.e., USA, Canada, and Argentina).

\section{Economic Impact of Mandatory Labeling for Hormone Induced Milk in the US}

Recombinant bovine somatotrophin (rBST or bST) is a growth hormone that occurs naturally in cows but is also produced by genetically altered bacteria in the laboratory. When injected into dairy cows every two weeks it increases lactation by 15-20 percent and feed efficiency by 10-15 percent raising the profit per cow per year on average \$100 (Butler, 1992). Although, Marion and Wills (1990) found little or no profits from using growth hormone for milk production, Tauer (2006) reported that the use of bST reduces cost of production by $\$ 0.23$ to $\$ 0.52$ per cwt per cow. The US Food and Drug Administration (FDA) approved the product for its use in 1994. Most of the scientific community such as, FDA, World Health Organization (WHO), American Medical Association (AMA), American Dietetic Association (ADA), and other US regulatory agencies concluded that milk produced form bST-induced cows are safe for human and animal consumption and allows voluntary labeling of such milk and milk products.

However, over the past sixteen years consumer associations and animal activists expressed strong opposition against the use of hormone in milk production. Independent researchers and critics say that milk from bST-treated cows contains higher levels of a different hormone - insulin-like growth factor (IGF-1) which has been linked to an increased risk of cancer in people. Further, the use of hormone increases the risk of udder inflammation among the dairy cows (a disease called mastitis) which is treated with antibiotics causing high residue of antibiotics in processed milk (Hansen and Perry, 2008). Consumers perceive bST-treated milk as unsafe and health risk because of its unknown long term effect on human health. Currently labeling milk and milk products is voluntary in the US however, more and more U.S. consumers are demanding more information on the content and characteristics of milk and milk products from mandatory labeling.

Most of studies in the literature found consumers are willing to pay a premium for bST-free milk and have expressed their intention to reduce milk consumption if bST-free milk is not available in the market (Chakraborty, 2005). In response to the growing consumer demand for bST-free milk some of the major retailers in the US have stopped buying hormone induced milk from dairy farmers and milk cooperatives (i.e., Wal Mart, Dillions, Kroger, Safeway, Food-4-Less, Fred Meyer, Smiths, Starbucks Coffee, Dannon, General Mills, and Ben and Jerry Ice Cream) Several countries in the world banned the use of bST for milk production such as, Japan, Australia, New Zealand, Canada, and all 27 nations of the European Union. Several state such as, Vermont, Maine, Pennsylvania, Indiana, and New Jersey have made mandatory labeling for milk and milk products using hormone.

The economic impact of mandatory labeling is based on data collected by the author from a main-in-survey in 2002-03. The survey was designed to collect information on consumers' level of knowledge on the bST technology, their willingness to pay for bST-free milk, and their socio-economic background. Based on their responses consumers were also asked how much milk (gallons/week) they would be willing to buy if bST-free milk were available and sold at a price higher than what they currently pay by $\$ 0.20, \$ 0.40, \$ 0.80$, and $\$ 1.00$ per gallon. For the other group, who are willing to buy bST-treated milk were asked how much (gallons/week) would be their consumption if the bST-treated milk would be sold at a lower price than what they currently pay by $\$ 0.10, \$ 0.40$, $\$ 0.70$, and $\$ 1.00$ per gallon. The details of the survey questionnaire and the methodology are beyond the scope of this paper however, the readers can consult Chakraborty (2005).

Only the definition of the variables used to estimate two demand equations (bST-treated and bST-free) and to measure the consumer and producer surplus are reported in Table-1. Initially, 38 percent of the respondents were unwilling to pay a premium, 26 percent were willing to pay a premium, and 36 percent were uncertain. However when these "uncertain" respondents were further exposed to a different set of questions including price discounts for 
bST-milk and premium for bST-free milk, 19 percent of these respondents changed their decision in favor of 'bST-treated' milk and 61 percent changed in favor of 'bST-free' milk. After rearranging the consumers according to their willingness to pay the final percentage for the entire sample turned out as this: 45 percent favored bST-treated milk, 47 percent favored bST-free milk, and 8 percent still remained undecided. For simplicity and convenience these 'uncertain' consumers were later arbitrarily assigned to the group that is willing to buy 'bST-treated' milk. As a result, the total percent of consumers willing to buy bST-induced milk increased to 53 percent.

In order to estimate the economic value (sum of consumer and producer surplus) from milk market segmentation the elasticity of demand for both bST-induced and bST-free milk was estimated from the respective demand equations using ordinary least square regression

The empirical estimation of the demand curves are based on the following linear specification:

$$
\text { Demand }_{b S T / n o n-b S T}=\alpha+\beta_{1} \text { Price }+\beta_{2} \text { Child }+\beta_{3} \text { Family }+\beta_{4} \text { Race }+\beta_{5} \text { Married }+\beta_{6} E d u+\varepsilon
$$

Estimated coefficients of the demand equations using ordinary least square regression are reported in Table 2 . The $\mathrm{F}$ statistics for both equations are significant although the coefficients of determination are low but reasonable considering most of the explanatory variables in this model are either binary or categorical and the data is cross-section. Most of the coefficients have expected sign and are significant, except for the coefficient on PRICE. One of the possible reasons for insignificant PRICE coefficient might be the aggregation bias. Since the real price for bST-induced milk is not existent in the market at the time the survey was conducted, the information on this variable is interpolated from the consumers' responses on their willingness to pay a higher price for such milk at incremental prices. The negative coefficient on PRICE implying $\$ 1.00$ increase in price would reduce quantity demanded for bST-treated milk by 0.37 gallon and for bST-free milk by 0.18 gallon. The point price elasticity of demand for bST-treated milk and bST-free milk are calculated as -0.20 and -0.12 , respectively. This suggests that for a one percent increase in price the demand for bST-treated and bST-free milk would decrease by 0.20 and 0.12 percent, respectively. Own price elasticity suggests bST-free milk is more inelastic than bST-induced milk. Consistent with the literature a linear supply curve with unit elasticity of supply is assumed for simplicity and convenience measuring producers' surplus. According to a study by Blayney (2002) the total quantity of milk produced and supplied in Kansas in 2002 is 1,520 million pounds at a price of $\$ 12.61$ per thousand weights (cwt) this information is used in the current study.

The economic impact of mandatory labeling for bST-milk was analyzed under two hypothetical market scenarios. In Table 3 Scenario-1, it is assumed that only bST-treated milk is available in the market (voluntary labeling) as a result, 47 percent of the consumers who preferred bST-free milk would stop buying milk reducing the demand by equal percentage (i.e., 47 percent). When compared to some of the studies done in other states the percentage of respondents unwilling to buy hormone induced milk in Kansas is relatively high (the national average is 20 percent). The argument that such consumers might buy organic milk if bST-free milk is not available in the market is not a viable proposition because the price of organic milk is much higher than regular milk and currently its market share is only 3 percent. It is expected that the use of bST technology would increase milk supply and reduce its price. In Scenario-1 it is assumed that although the supply increases by 10 percent, price remains same. The estimated consumers' surplus, producers' surplus, and the total surplus in Scenario-1 are $\$ 26,510, \$ 2,170$, and $\$ 28,680$, respectively (2002-03 prices).

In Table 3, Scenario-2 it is assumed that (under mandatory labeling) both bST-treated and bST-free milk is available and two distinct milk markets exist. Under this situation the total surplus from the segmented milk market is the sum of the consumers' and producers' surpluses generated from the two markets. Scenario-2A represents the market for bST-treated milk, assuming supply increases by 10 percent and price decreases by 15 percent. Scenario-2B represents the market for bST-free milk, assuming supply does not change but the price increases by 20 percent. The surplus generated from bST-treated milk and bST-free milk under Scenario 2A and 2B are \$31,670.84 and $\$ 41,215.16$, respectively (in $2002-03$ prices). The total surplus under Scenario-2 is $\$ 72,886.00$. This total surplus (or the economic value) from Scenario-2 is 250 percent higher than the total surplus generated from Scenerio-1. The empirical study suggests that under certain assumptions, the milk market segmentation would generate higher social benefit.

The effectiveness of market segmentation based on real or perceived product differentiation largely depends on how long the market would be separated. So far, it is assumed that there is no real difference in the marketing cost between single and differentiated markets. If it does, then further empirical research should be directed measuring the social cost and benefit of market segmentation under mandatory labeling. 


\section{Summary and Conclusions}

This study suggests that the producers of bST-free milk would be benefitted from market segmentation due to mandatory labeling because they would be able to sell their product at a higher price when equilibrium is established. This is primarily because a large percentage of consumers are willing to pay a higher price for bST-free milk. For example, bST-free milk can be priced higher than conventionally priced milk but lower than organic milk.

Pew Foundation survey reported that 29 percent of Americans strongly oppose GM food and they believe that these products are unsafe (Lendman, 2008). The US supermarket tests have revealed that at least 70 percent of all foodstuffs contain GM product. The US Consumers Union is calling for mandatory safety checks before any GM food is able to be sold. The research by the National Academy of Sciences indicated that toxic and allergenic substances may be introduced through the genetic engineering which might be difficult to "predict and assess unintended adverse effects on human health." (ABC-News, 2004)

In total disregard to consumers' demand for mandatory labeling the US Food and Drug Administration (FDA) approved the meat and milk from cloned animals as food for human consumption. The FDA does not require food made from cloned animals and their offspring to be labeled but the producers could apply for the right to label their foods as "clone-free." In an opinion poll survey on Food and Biotechnology by Pew Initiative in 2006 it is found that 64 percent of Americans were uncomfortable with animal clones and strongly believe on mandatory labeling for such products. A recent national food safety and labeling poll conducted by the Consumer Reports National Research Center reveals that 95 percent of the Americans agree that food products made from genetically engineered animals should be labeled. Ninety four percent of the Americans agree that the meat and dairy products from cloned animals should be labeled. The study also found that 6 out of 10 Americans would not buy meat or milk products from genetically engineered animals or milk/milk products from cloned animals or their offspring (Reed Business Information, 2009).

A research by the International Dairy Foods Association estimated that the $\$ 20$ billion dairy market could fall 15 percent if cloned milk is introduced (CBS4, 2008). Consumer groups, including the Consumer Federation of America have argued that more precautions should be made to protect the safety of food supply and food products made from cloned animals which must be separated and labeled.

\section{References}

ABC-News (2008). Many US Consumers Oblivious to GM Food Fears. [online], [cited Jan 17, 2008], Available from: http://www.abc.net.au/news/stories.

APN-Asia Pulse News (2003). Producers, Sellers, Urged to Label GM Food in China. [online], [cited July 31, 2003], Available from: http://www.english.peopledaily.com.cn.

Blayney, D. P. (2002). The Changing Landscape of U.S. Milk Production. Statistical Bulletin. No. 978. United States Department of Agriculture, Economic Research Services.

Butler, L.J. (1992). Economic Evaluation of bST for onfarm use. In M.C. Halberg (Ed.). Bovine somatotropin and emerging issues: as assessment, Boulder, CO: Westview Press.

CBS4 (2008). Meat from Cloned Animals Approved by FDA. [online], [cited Jan 16 2008], Available from: $<$ http://www.cbs4.com/cosnumer/cloned.food.animal.2.630258.html $>$

Chakraborty, K. (2006). Product Labeling and Economic Value of Milk Market Segmentation. Journal of International Food and Agribusiness Marketing. 18(1/2). 9-27.

Chakraborty, K. (2005). Consumers' Attitude Toward Hormone-free Milk: What Have We Learned? Applied Economics Letters, 12(10). 633-637.

Chang, X. (2007). Labeling Policy and Impact on Consumer's Purchasing Behavior in China: A Case Study of Vegetable Oil in Nanjing. In International Food Policy Research Institute (IFPRI) and Research and Information System for Developing Countries (RIS).

Cloutier, M. (2006). Economic Survey on the Costs Relating to Mandatory Labeling of the Genetically Modified (GM) versus non-GH at the Quebec Level. Report Presented to the Ministry of Agriculture. University of Quebec in Montreal, Department of Management and Technology.

Crespi, J.M., \& Marette, S. (2003). Does Contain versus Does Not Contain. Does it Matter Which GMO Label is Used? European Journal of Law and Economics, 16, 327-344.

Curtis, K.R., J.J. McCluskey., \&T.I. Wahl (2004). Consumer Acceptance of GM Products in the Developing World. AgBioForum, 7(1/2). 70-75. 
Curtis, K.R., \& Moeltner, K. (2006). Do Attitude Toward Genetically Modified Foods Influence in Primary Trading Countries? The Case for China and Romania. Canadian Journal of Agricultural Economics, 54(2). 289-310.

De Leon, A., Manalo, A., and Guilatco, F.C. (2004). The Cost Implications of GM Food Labeling in the Philippines. Study Commissioned by the Bureau of Food and Drugs, Department of Health, Republic of Philippines.

Fulton, M., \& Giannaken, K. (2004). Inserting GM products into the Food Chain: The Market and welfare Effect of Different Labeling and Regulatory Regimes. American Journal of Agricultural Economics, 86(1). $42-60$.

Generic Modifications. Mar 20 (2008). at gm.org/?p=61.

Gruere, G.P., \& Rao, S.R. (2007). A Review of International Labeling of Genetically Modified Food to Evaluate India's Proposed Rule. AgBioForum, 10(1). 51-64.

Hansen, M. \& Perry, R. (2008). Lobbyists Try to Keep Milk Information from Consumers. CommonDreams (April 1) Internet @ http://www.commondreams.org

Ho, P., \& Vermeer, E.B. (2004). Food Safety Concerns and Biotechnology: Consumers' Attitude to Genetically Modified Products in Urban China. AgBioForum, 7(4). 158-175.

Hu, W., \& Chen, K. (2004). Can Chinese Consumers be Persuaded? The Case of Genetically Modified Vegetable Oil. AgBioForum, 7(3). 124-132.

Huang, J. R., Hu, H. van Meijl, and E. van Tongeren. (2004). Biotechnology Boosts to Crop Productivity in China: Trade and Welfare Implications. Journal of Development Economics, 75, 27-54.

ISAAA (2008). International Services for the Acquisition of Agribiotech Applications Labeling GM Food. Pocket-K, No-7 (Undated).

Jin, S., J. Huang., R. Hu., and S.D. Rozelle. (2002). The Creation and Spread of Technology and Total Factor Productivity in China. American Journal of Agricultural Economics, 84(Nov). 916-930.

Kiesel, K., Buschena, D., \& Smith, V. (2002). Consumer Acceptance and Labeling of GMOS in Food Products: A Study of Fluid Milk Demand. Paper presented at the $6^{\text {th }}$ International ICABR Conference, Ravello, Italy, July 11-14, 2002.

KMPG International, March (2000). Reports on the Costs of Labeling Genetically Modified Foods.

Lendman, S. (2008). Potential Health Hazards of Genetically Engineered Foods, Global Research. Feb 22. [online] Available from: http://globalresearh.ca.

Li. Q., Curtis, K.R., McCluskey, J.J., \& Wahl, T.I. (2002). Consumer Attitude Toward Genetically Modified Food in Beijing, China. AgBioForum, 5(4). 145-152.

Lin, W., Somwaru, A., Tuan, F., Huang, J., and Bai, J. (2006). Consumer Attitude Toward Biotech Food in China. Journal of International Food and Agribusiness Marketing, 18(1/2). 177-203.

Lin, W., Tuan, F., Dai, Y., Zhong, F, and Chen, X. (2008). Does Biotech Labeling Affect Consumers' Purchasing Decisions? A Case Study of Vegetable Oils in Nanjing, China. AgBioForum, 11(2). 123-33.

Mahr, K. 2008. China's Genetically Altered Food Boom. Time Magazine, Feb 18, 2008, [online], Available from : http://www.time.com.

Marion, B.W., \& Wills, R.L. (1990). A prospective assessment of the impacts of bovine somatotropin: a case study of Wisconsin. American Journal of Agricultural Economics, 72, 326-36.

NERA National Economic Research Associates. (2001). Economic Appraisal of Options for Extension of Legislation on GM Labeling: A Final Report for the Foods Standards Agency of the United Kingdom.

Pengali, P.L., M. Hossian., \& R.V. Gerpacio. (1997). Asian Rice Bowls. Wallingford, UK. CAB International.

Petry, M., \& W. Bubang. (2008). China Biotechnology Update. Beijing, [online] Available from: http://www.resourcesInvestor.com.

Reed Business Informatics, Division of Reed Elsevier Inc. (2009). Source Consumer Report. [online], [cited Feb 4, 2010], Available from : http://www.packagingdigest.com/article/print/341952.

Rosegrnt, M. W., M. S. Paisner, S. Meijer., and J. Witcover. (2001). Global Food Projection to 2020. Washington, DC. International Food Policy Research Institute.

Rubenstein, E. (2000). China's Leader Comment to Basic Research, Global Science. Science, 288, 1950-1953

Soregaroli, C., Boccaletti, S., \& Moro, D. (2003). Consumer's Attitude Towards Labeled and Unlabeled GM Food 
Products in Italy. Paper presented at the IAMA World Food and Agribusiness Forum, June 23-24, Cancun, Mexico. SSTC - State Science and Technology Commission. (1990). Development Policy of Biotechnology. The Press of Science and Technology, Beijing, China.

Tauer, W.L. (2006). Impact of Recombinant Bovine Somatotropin on Dairy Farm Cost of Production: Evidence from Multiyear Data. AgBioForum, 9(2). 79-83.

Wang, Q., Halbrendt, C., Kolodinsky, J., \& Schmidt, F. (1997). Willingness to pay for the rBST-Free Milk: A Two-limit Tobit Model Analysis. Applied Economic Letters. 4, 619-621.

Zhong, F., Marchant, M., Dong, Y., and Lu. K. (2003). GM Foods: a Nanjing Case Study of Chinese Consumers' Awareness and Potential Attitude, AgBioForum, 5(4). 136-144.

Table 1. Definition and Descriptive Statistics of the Variables Used in the Model

\begin{tabular}{|c|c|c|c|}
\hline Variable & Definition & Mean & $\begin{array}{l}\text { Standard } \\
\text { Deviation }\end{array}$ \\
\hline MILKLABEL & Do you support mandatory labeling for bST-produced milk? yes $=1$, otherwise $=0$ & 0.7467 & 0.4352 \\
\hline KNOWLEDG & Do you feel more information is needed about bST-produced milk? yes $=1$, otherwise $=0$ & 0.8832 & 0.3214 \\
\hline HEALTH & $\begin{array}{l}\text { Do you believe human health is at risk by using bST in food products? yes }=1 \text {, } \\
\text { otherwise }=0\end{array}$ & 0.1496 & 0.3570 \\
\hline TRUST & $\begin{array}{l}\text { For compliance of recommended guidelines using bST for milk production how much } \\
\text { you think FDA should be responsible? } 1=\text { not responsible; } 2=\text { somewhat; } 3=\text { very } \\
\text { responsible }\end{array}$ & 2.8174 & 0.4849 \\
\hline FOODLABEL & $\begin{array}{l}\text { Do you think government should pass regulation requiring food labels for all products } \\
\text { where bST has been used? } \\
\text { 1=unnecessary; } 2=\text { somewhat necessary; } 3=\text { absolutely necessary }\end{array}$ & 2.8120 & 0.3756 \\
\hline QUANT & Quantity of milk currently consumed by the respondents in gallons (continuous variable) & 5.0769 & 4.7198 \\
\hline SEX & Female $=1$, Male $=0$ & 0.5131 & 0.5002 \\
\hline CHILD & $\begin{array}{l}\text { If the family have any children below } 12 \text { years of age. } \\
\text { yes }=1 \text {, otherwise }=0\end{array}$ & 0.4095 & 0.8677 \\
\hline FAMILY & Total number of members in the family (continuous variable) & 2.6743 & 1.5527 \\
\hline AGE & Age of the respondent (continuous variable) & 51.781 & 12.1514 \\
\hline INCOME & $\begin{array}{l}\text { Total household income of the respondent } \\
\text { (\$) (continuous variable) }\end{array}$ & 57,242 & 28,548 \\
\hline EDUCATION & $\begin{array}{l}\text { Educational level of the respondent. } 1=\text { high school and below; } 2=\text { some college; } \\
3=\text { college degree and above }\end{array}$ & 2.3371 & 0.7349 \\
\hline
\end{tabular}


Table 2. Estimates of Linear Demand Equations for bST and non-bST milk (Dependant variable = quantity of milk consumed)

\begin{tabular}{lllll}
\hline \multirow{2}{*}{ Variables } & \multicolumn{3}{c}{ bST-Treated } & \multicolumn{2}{c}{ bST-Free } \\
\cline { 2 - 5 } & Coefficient & t-stat & coefficient & t-stat \\
\hline CONSTANT & $3.676^{*}$ & 2.653 & 1.028 & 0.755 \\
PRICE & -0.366 & -1.149 & -0.186 & -0.602 \\
CHILD & $0.487^{* *}$ & 1.640 & $0.547^{* *}$ & 1.809 \\
FAMILY & $0.982^{*}$ & 4.781 & $0.469^{*}$ & 2.497 \\
RACE & $-2.236^{*}$ & -2.742 & $1.383^{* *}$ & 1.894 \\
MARITAL STATUS & $0.831^{* *}$ & 1.716 & 0.326 & 0.718 \\
EDUCATION & 0.315 & 1.130 & $0.390^{* *}$ & 1.609 \\
R-square & 0.28 & & 0.14 & \\
F-statistic & 17.83 & & 7.96 & \\
Observations & 282 & & 298 & \\
\hline
\end{tabular}

$*$ and ** indicate coefficients are significant at .05 and .20 levels, respectively

Table 3. Mandatory Labeling and Economics Value for Milk Market Segmentation

\begin{tabular}{|c|c|c|c|c|}
\hline \multirow[t]{2}{*}{ Demand Curve } & \multirow[t]{2}{*}{ Supply Curve } & Consumer & Producer & Total \\
\hline & & Surplus (\$) & Surplus (\$) & Surplus (\$) \\
\hline
\end{tabular}

\section{$\underline{\text { Scenario-1 }}$}

Complete bST-treated milk market: assuming 47\% consumers will stop or reduce milk consumption and supply of milk increased by $10 \%$ with no price change $(\mathrm{Q}=$ Quantity, $\mathrm{P}=$ Price $)$

$\mathrm{Q}_{\mathrm{bST}}=820.97-0.86 * \mathrm{P} \quad \mathrm{Q}_{\mathrm{bST}}=132.59 * \mathrm{P}$ $26,510.42$ $2,170.31$ $28,680.73$

$\underline{\text { Scenario-2 }}$

Segmented milk market assuming 53\% consumers (after adding $8 \%$ undecided consumers) will buy bST-treated milk and $47 \%$ will buy bST-free milk

$2 \mathrm{~A}$ - Market for bST-treated milk assuming price decreased by $15 \%$ and supply increased by $10 \%$

$\mathrm{Q}_{\mathrm{bST}}=966.75-12.78 * \mathrm{P}$

$\mathrm{Q}_{\mathrm{bST}}=82.74 * \mathrm{P}$

$4,237.29$

$27,433.55$

$31,670.84$

2B - Market for bST-free milk assuming price increased by $20 \%$ with no change in supply

$\mathrm{Q}_{\mathrm{bST}}=800.13-6.79 * \mathrm{P}$

$\mathrm{Q}_{\mathrm{bST}}=42.21 * \mathrm{P}$

$5,180.31$

$36,034.85$

$41,215.16$ 